University of Texas Rio Grande Valley

ScholarWorks @UTRGV

$10-2020$

\title{
Epidemiological implications of the genetic diversification of dengue virus (DENV) serotypes and genotypes in Mexico
}

\author{
Ericel Hernandez-Garcia \\ Maria de Lourdes Munoz \\ Randy E. David \\ Gerardo Perez-Ramirez \\ Joel Navarrete-Espinosa
}

See next page for additional authors

Follow this and additional works at: https://scholarworks.utrgv.edu/som_pub

Part of the Genetic Phenomena Commons

\section{Recommended Citation}

Hernández-García, E., Muñoz, M. de L., David, R. E., Pérez-Ramírez, G., Navarrete-Espinosa, J., Díaz-Badillo, Á., Domínguez-de-la-Cruz, E., Moreno-Galeana, M., \& Brito-Carreón, C. A. (2020). Epidemiological implications of the genetic diversification of dengue virus (DENV) serotypes and genotypes in Mexico. Infection, Genetics and Evolution, 84, 104391. https://doi.org/10.1016/j.meegid.2020.104391

This Article is brought to you for free and open access by the School of Medicine at ScholarWorks @ UTRGV. It has been accepted for inclusion in School of Medicine Publications and Presentations by an authorized administrator of ScholarWorks @ UTRGV. For more information, please contact justin.white@utrgv.edu, william.flores01@utrgv.edu. 


\section{Authors}

Ericel Hernandez-Garcia, Maria de Lourdes Munoz, Randy E. David, Gerardo Perez-Ramirez, Joel Navarrete-Espinosa, Alvaro Diaz-Badillo, Eduardo Dominguez-de-la-Cruz, Miguel Moreno-Galeana, and Cesar Armando Brito-Carreon 


\section{Epidemiological Implications of the Genetic Diversification of Dengue Virus (DENV) Serotypes and Genotypes in Mexico}

Ericel Hernández-García ${ }^{\mathrm{a}}$, María de Lourdes Muñoz ${ }^{\mathrm{a}^{*}}$, Randy E. David ${ }^{\mathrm{b}}$, Gerardo Pérez-

Ramírez ${ }^{\mathrm{a}}$ Joel Navarrete-Espinosa ${ }^{\mathrm{c}}$, Álvaro Díaz-Badillo ${ }^{\mathrm{d}}$, Eduardo Domínguez-de-laCruz $^{\mathrm{a}}$, Miguel Moreno-Galeana ${ }^{\mathrm{a}}$, Cesar Armando Brito-Carreón ${ }^{\mathrm{a}}$

${ }^{a}$ Department of Genetics and Molecular Biology, Center for Research and Advanced Studies of the National Polytechnic Institute (CINVESTAV_-lr N), Mexico City, Mexico; 'baboratories of Biological Anthropology, Uni els ty of Kansas, Lawrence, KS, USA; ${ }^{c}$ Epidemiology Division, Coordination of $\mathrm{In}_{\mathfrak{w}}$ 'orated Health Programs, Mexican Social Security Institute, Mexico City, Mexa'n; 'University of Texas, Rio Grande Valley, Department of Human Gene tic a .ld South Texas Diabetes and Obesity Institute, TX, USA.

Corresponding author:

Professor Maria de Lourdes Munuz, Ph.D. Centro de Investigación y a Escudios Avanzados del IPN, Av. Instituto Politécnico 1 'ac onal 2508, San Pedro Zacatenco, Gus avo A. Madero Tel: 5255-5747333د, Fid. 555-123456

Email:1munoz@cinves'av.mx

Emails:

Ericel Hernández-García: ericledimp@gmail.com Maria de Lourdes Muñoz: lmunoz@ cinvestav.mx Randy E. David: r528d912@ku.edu Gerardo Pérez-Ramírez: gperezr@ cinvestav.mx Joel Navarrete-Espinosa: jonaes2003@yahoo.es Álvaro Díaz-Badillo: alvaro.diazbadillo@uth.tmc.edu Eduardo Domínguez-de-la-Cruz: edomiguez@cinvestav.mx Cesar Armando Brito-Carreón: cesarbrito@ cinvestav.mx 


\section{Abstract}

Variation and clade shifts in dengue virus (DENV) genotypes are responsible for numerous dengue fever outbreaks throughout Latin America in the past decade. Molecular analyses of dengue serotypes have revealed extensive genetic diversification and the emergence of new genotypes in Brazil (DENV-4 genotype I) and elsewhere in tropical and subtropical America. The goal of the present study is to assess the extent to which the adventitious introduction of DENV genotypes and their increasing genetic diversity affects dengue epidemiology in Mexico. A nuanc $\mathrm{d} s$ 'quence inspection and phylogenetic analysis of the C-prM nucleotide region o. DE VV was performed for specimens collecting in 2009 from the Veracruz Stıte, Niexico. Findings were contrasted with specimens collected in adjacent vuars and analysed based on the epidemiological patterns reported between 99v and 2019. Additionally, the identification process of various DENV _enotypes was assessed, including: (1) DENV1, genotype $\mathrm{V},(2)$ the DENV-2 As: $\mathrm{n} / \mathrm{i}$ merican and Asian II genotypes (3) DENV-3, genotype III, and (4) DENV-4 ge.ntype I. This resulted in the discovery of a distinct genetic cladistic pattern fo: st - ntype DENV-2. Lastly, study findings suggest that a correlation exists betw e.t. the emergence of novel genotypes and genetic diversification, with the increasing incidence of DENV infections in Mexico in 2009.

Keywords: emergence of new genotypes; geographic distribution of DENV serotypes; phylogenetic analysis of dengue; dengue epidemiology 


\section{Introduction}

In tropical and subtropical America today, the co-circulation of dengue (DENV), zika (ZIKV) and chikungunya (CHIKV) viruses is a major public health concern. The transmission of these diseases is dependent on mosquito vectors, specifically, the "bite" of infected Aedes aegypti or Aedes albopictus mosquitoes. Mass human population movement, climate change, and the introduction of novel technologies (related to agriculture, construction, damming, etc.) have contributed to the geographic redistribution and expansion of the range of mosquito vectr rs a nd the diseases that they transmit (Ryan et al., 2018).

Aedes aegypti is the principal dengue vectc du to its enhanced viral replication capacity, therefore causing an increased likeli' ord of DENV transmission (Clyde et al., 2006). Since the vector was introduced $11 \mathrm{~m} \wedge^{\wedge}$ frica in the $17^{\text {th }}$ century, various DENV genotypes have been recorded (Mnore et a.., 2013; Gubler, 2004). Symptoms of these infections are similarly, making $a \approx \mathrm{c}^{\text {n+e }}$ diagnoses difficult. Nonetheless, dengue transmission in the Americas in?s been carefully monitored for approximately 50 years. Notably, its incidence has in -eased dramatically over the last quarter-century.

Most dengut ini ¿ ^ons are asymptomatic, although mild to moderate symptoms may occur, including: fever, malaise, headache, retro-orbital pain, myalgia, arthralgia, nausea/vomiting, and rash (Murray et al., 2013). In cases of "severe dengue", or dengue haemorrhagic fever (DHF) - the primary symptom are plasma leakage (vascular permeability) that may result in pleural effusion and dyspnoea, leading to dengue shock syndrome (DSS), possibly causing the death of the patient (Huy et al., 2013). More than 50 million dengue fever cases occur each year worldwide, resulting in $\sim 24,000$ deaths annually (Huy et al., 2013). In Mexico, 548,000 cases of dengue fever and 153,682cases of severe dengue were reported between 1990 and 2019 (Dirección 
General de Epidemiología, 2020). Although dengue is the most common vector-borne viral disease worldwide, few studies have investigated the underlying relationship between disease epidemiology and evolutionary virology, specifically the influx of genetic diversity and novel genotypes. This relationship becomes increasingly convoluted with the presence of concomitant chikungunya and zika virus infections (Mercado-Reyes et al., 2019).

Globally, DENV-2 was the predominant dengue serotype reported between 1990 and 2004. Between 2005 and 2009, coinfections among all fou serotypes (DENV-1 Denv-4) largely characterized outbreaks. After 2009, vá ious serotypes predominated in different regions of the world. DENV-1 and DENV $-\angle$ vere the most common serotypes in Africa and the Americas; DENV-1 was most $n_{1}$ evalent in Europe; coinfection among all four serotypes predominated in the eastc $n$ Mrediterranean (Levant); and DENV-1 was the most common serotype in the $w$. stern Pacific (Oceania) (Cisneros-Solano et al., 2004; Guo et al., 2017). These res ${ }^{{ }^{1+}}$, . Ithough valuable as a global distribution overview, do not inform the ge $\mathrm{og}_{1}$ ?nnic fine-mapping of dengue serotypes and genotypes which are etiolo ${ }_{2}^{-i} \dot{c}^{\prime 1} . \mathrm{y}$ dependent on climate and distinct viral evolution trajectories. Such micr eev lutionary patterns are more readily apparent in phylogeographic analys zs (Cisneros et al., 2006; Gardella-Garcia et al., 2008; Pinheiro and Corber, 1997; Rico-Hesse et al., 1997).

DENV serotypes emerged in the Americas beginning with DENV-1 in 1977. By 1981, DENV-2 and DENV-4 appeared, and in 1994, a novel DENV-3 genotype emerged. These developments resulted in a shift from nonendemicity or hypoendemicity, to hyperendemicity, and ultimately, the arrival of severe dengue, reported between 1981 and 1997 in 24 American countries (Gubler, 1998; Pinheiro and Corber, 1997). Severe dengue was first reported in Mexico among eight patients in 
1985. By 1995-1996, 539 cases of severe dengue, including 30 deaths were reported. During this same period, Mexican dengue endemicity was established, and later confirmed in Oaxaca State in 2010 (Istúriz et al., 2000; Torres-Galicia et al., 2014). Significant epidemics of serotype DENV-1 occurred throughout numerous Mexican States between 1979 and 1983, including: Chiapas, Mexico State, Guerrero, Hidalgo, Jalisco, Michoacán, Oaxaca, Puebla, Querétaro, Quintana Roo, San Luis Potosí, Tabasco, Tamaulipas, Veracruz, and Yucatán. Serotype DENV-2 first appeared in Oaxaca and Tamaulipas in 1982. DENV-3 was introduced in C1'`pas, Puebla, San Luis Potosi, Tamaulipas and Veracruz in 1995. Lastly, cases or . TElV-4, the least common dengue serotype in Mexico, was reported in Yucatán uı 1984 (Loroño-Pino et al., 1993). By 1996, DEN-4 was reported in Oaxaca, Veracru: a. 'd other Mexican States (CisnerosSolano et al., 2004; Cisneros et al., 2006; Drn s t al., 2014; Falcón-Lezama et al., 2009; Gardella-Garcia et al., 2008). T.• v ariable geographic distribution of dengue serotypes corroborates the complex and dynamic nature of DENV introduction across Mexico.

In 2009, Hurricane Ida flooded the States of Veracruz, Tabasco, and Jalisco creating an ideal breer'ing ground for mosquito vectors, leaving many people susceptible to infection. During the subsequent dengue outbreak, the Mexican Epidemiological Surveillance Single Information System-SINAVE (DREF, 2009) reported 41,687 confirmed cases of dengue fever in Veracruz, representing a $30 \%$ increase from the previous year. A total of 7,898 of these cases were classified as severe dengue. There were an additional 11,222 unconfirmed cases reported as well (DREF, 2009).

Studies have shown that DENV strains possess variable levels of virulence (Rodriguez-Roche and Gould, 2013). For example, the occurrence of particularly severe 
DHF in Cuba in 1981 was linked to the introduction of a Southeast Asian strain of DENV-2 (Rico-Hesse et al., 1997; Gardella-Garcia et al., 2008). Subsequently, an extended outbreak of DHF/DSS arose in Venezuela, Mexico, Colombia, and Brazil, linked to the same Southeast Asian strain of DENV-2 (Rico-Hesse et al., 1997). In 1995, following a 5-year DENV-1 epidemic, a novel DENV-2 epidemic (American genotype) was reported in Peru (Kochel et al., 2002). This indicated that the American DENV-2 genotype strain lacked the properties necessary to cause the development of severe disease. This episode corroborates earlier findings that as ociate the DENV-2 American genotype with mild disease and the DENV-2 su theast Asian genotype with the appearance of DHF in the Americas (Rico-Hesse eı १l., 1997). Viral virulence and immune response are hence considered two key deter. ninants in the pathogenesis of DHF. In agreement with other researchers, " $v \mathrm{vv}_{2}$,othesize that the displacement of one genotype by another more pernicious $: \mathfrak{D}^{f}$ will precipitate severe dengue. This system operates within the context of vector tensity, in turn influenced by climate and ecological factors. To investigate th is hypothesis, it is vital to have continuous epidemiological surveillance sysums in place to detect the transmission of distinctive dengue virus genotypes oi a' $\mathrm{h}$ serotype.

The objective $0^{-}$this study is to analyse dengue epidemic trends between 1990 and 2019, and to assess DENV serotypes and genotypes from the 2009 Mexican epidemic, specifically. Results will contribute to the development of a future surveillance program, integral to controlling the most virulent forms of this disease.

\section{Material and Methods}

\subsection{Viruses}


The serotypes of DENV used in this study were as follows: DENV-1 Hawaii, DENV-2 New Guinea C (NGC), DENV-3 H-87, and DENV-4 H-341. All control samples were supplied by the Division of Vector-borne Infectious Diseases, Centers for Disease Control and Prevention, Fort Collins, CO, USA. Additionally, sixty-five isolates of DENV virus were obtained from acute-phase plasma collected from patients with dengue fever or severe dengue through the Instituto Mexicano del Seguro Social (IMSS) from Veracruz State in 2009. Samples were anonymized, with only information regarding disease symptomology available. This study was annı-ved by the Institutional Review Board of the IMSS (Commission of Scientific Pes arch) and the Bioethical Commission for Research in Humans of the Center fot ?esearch and Advanced Studies of the National Polytechnic Institute (Comité de B’ot: a Para la Investigación en Seres Humanos, COBISH-CINVESTAV). All e $\mathfrak{k}^{\prime} \cdot m . s$ logical data was obtained through the Mexican SINAVE (Dirección Gei ara' de Epidemiología, 2020).

\subsection{DENV infected cells and virus ison tion}

Aedes albopictus clone C6/د6 cells were grown in minimal essential media (MEM), supplemented with : \%\% fetal bovine serum (FBS) and nonessential amino acids. Cells were mair ain $\mathrm{d}$ at $28{ }^{\circ} \mathrm{C}$ without carbon dioxide $\left(\mathrm{CO}_{2}\right)$. After 18 hours of culture, cells $\left(2 \times 10^{6 / 1} \mathrm{J0} \mathrm{mm}\right.$ plate) were infected with $0.2 \mathrm{ml}$ DENV-2 inoculum with an input MOI of $600 \mathrm{PFU} / c e l l$, and were incubated at $28{ }^{\circ} \mathrm{C}$ for 10 days.

Viruses were isolated as described by Cisneros et al. (2006), with a few modifications. After 18 hours of culture, C6/36 cells $\left(2 \times 10^{6} / 15 \mathrm{ml}\right.$ tube) were infected with 0.01 to $0.1 \mathrm{ml}$ of serum specimen per tube, diluted to $1.0 \mathrm{ml}$ with medium, and incubated for 2 hours at $28^{\circ} \mathrm{C}$. After one wash, $3.0 \mathrm{ml}$ of MEM was added, and cells were cultivated for approximately 15 days at $28{ }^{\circ} \mathrm{C}$ (passage number 1 ). Cells were observed daily and when a cytopathic effect was apparent from syncytium formation 
and cellular lysis, cells were harvested and centrifuged at 3,000 rpm for $5 \mathrm{~min}$. The pellet was then suspended in $0.6 \mathrm{ml}$ of MEM and stored in aliquots of $0.15 \mathrm{ml}$ at -70 ${ }^{\circ} \mathrm{C}$. The supernatant (approximately $2.5 \mathrm{ml}$ ) was stored in 2 aliquots of $1.0 \mathrm{ml}$ and one aliquot of $0.5 \mathrm{ml}$, at $-70{ }^{\circ} \mathrm{C}$. To obtain passage numbers two and three, $\mathrm{C} 6 / 36$ cells were incubated with $1.0 \mathrm{ml}$ of the supernatant obtained from earlier passages, for 2 hours at $28^{\circ} \mathrm{C}$, following the same procedure as above. Serotypes among all samples were determined based on the isolates obtained from the first, second, or third culture passages.

\subsection{RNA extraction procedure}

RNA was extracted from the cell culture $s_{i}$, ern tant using TRIzol ${ }^{\mathrm{TM}}$ LS reagent (Gibco, Gaithersburg, MD) according to the $\mathrm{r}$ lar.ufacturer's recommendations. Isopropanol-precipitated RNA was rec', ve ea hy centrifugation, and then air-dried. The resultant RNA pellet was suspended in 50,1 of diethyl pyrocarbonate (DEPC) (SigmaAldrich, St. Louis, MO) treated $v$ at $s_{1}$ 'nd used as a template for reverse transcription with polymerase chain reaction. (R'I-PCR).

\subsection{Reverse transcription nol 1 merase chain reaction (RT-PCR)}

The RT-PCR $ץ$ - otocol described in Seah et al. (1995) was used to discern DENV serotypes. Synthetic oligonucleotide primer pairs were designed according to sequence data for the following DENV strains: 16681, New Guinea C, and Jamaica 1409 (Seah et al., 1995). The following genes were then amplified and sequenced: (1) protein $\mathrm{C}-$ nucleotide 139 (C-139) to prM-789 (prM-789) (Gardella-Garcia et al., 2008), and (2) NS3 from nucleotides 4,899 (DV1) to 5,067 (DSP1), 4,899 (DV1) to 5,279 (DSP2), 4,899 (DV1) to 5,174 (DSP3) or 4,899 (DV1) to 5,342 (DSP4), for serotypes DENV-1, DENV-2, DENV-3 and DENV-4, respectively (Seah et al., 1995). All assays were 
performed using the SuperScript ${ }^{\mathrm{TM}}$ III One-Step RT-PCR System with Platinum ${ }^{\mathrm{TM}}$ Taq DNA Polymerase (Invitrogen/Thermo Fisher Scientific, Waltham, Massachusetts). A mixture of $5 \mu \mathrm{l}$ of total RNA $(0.1-0.5 \mu \mathrm{g})$, and $1 \mathrm{pmol} / \mu \mathrm{l}$ of each primer at nucleotide positions C-139 (forward, 5'-CAATATGCTGAAACGCGHG-3') and prM-789 (reverse, 5'-CCTTCNGMNGACATCC-3') was incubated at $65^{\circ} \mathrm{C}$ for 5 min. After adding $25 \mu 1$ of $2 \mathrm{X}$ Reaction Mix and $2 \mu \mathrm{l}$ of SuperScript ${ }^{\mathrm{TM}}$ III RT/Platinum ${ }^{\mathrm{TM}}$ Taq with DEPCtreated water (total volume: $50 \mu \mathrm{l}$ ), RT was carried out at $50{ }^{\circ} \mathrm{C}$ for $60 \mathrm{~min}$. This step was followed by incubation at $94{ }^{\circ} \mathrm{C}$ for 2 min to inactivate the ${ }^{2}$ verse transcriptase. Afterwards, Platinum ${ }^{\mathrm{TM}}$ Taq was activated by incubatior. a. $94{ }^{\circ} \mathrm{C}$ for $2 \mathrm{~min}$ to amplify the $629 \mathrm{bp}$ fragment of C-pM. This was followed bv $3 ;$ cycles with the following conditions: $94{ }^{\circ} \mathrm{C}$ for $30 \mathrm{~s}, 55^{\circ} \mathrm{C}$ for $45 \mathrm{~s}, 72{ }^{\circ} \mathrm{C}$ for w s, and a final extension of $72{ }^{\circ} \mathrm{C}$ for $10 \mathrm{~min}$ (storage at $4{ }^{\circ} \mathrm{C}$ ). Strains of DEN V 1. 2, -3 and -4 were used as positive controls for RT-PCR assays.

Serotypification was condirea ?ccording to the protocol of Seah et al. (1995): 10 cycles of $95^{\circ} \mathrm{C}$ for $30 \mathrm{sec}$, in $\mathrm{s}$ ang at $55^{\circ} \mathrm{C}$ for $1 \mathrm{~min}$, and extension at $72{ }^{\circ} \mathrm{C}$ for 1 min and 35 cycles of $95^{\circ} \mathrm{C}$ for $30 \mathrm{sec}, 55^{\circ} \mathrm{C}$ for $30 \mathrm{sec}$, and $72{ }^{\circ} \mathrm{C}$ for $30 \mathrm{sec}$, with a final extension of $72^{\circ}-\mathrm{Nr} / \mathrm{min}$ (storage at $4{ }^{\circ} \mathrm{C}$ ). In addition, the NS3 regionnucleotide positions 4, 99 to 5,067 (NS3-169) for DENV-1, and 4,910 to 5,174 (NS3265) for DENV-3, was obtained via an RT-PCR assay, as aforementioned, but with the following primers: (1) DV1 (forward, 5'-GGRACKTCAGGWTCTCC-3') and DSP1 (reverse, 5'-AGTTTCTTTTCCTAAACACCTCG-3') for DENV-1, (2) DV1 and DSP3 (reverse, 5'-TTAGAGTYCTTAAGCGTCTCTTG-3') for DENV-3, and (3) DV1 and DSP4 (reverse, 5' CCTGGTTGATGACAAAAGTGTTG 3') for DENV-4. 
For automated sequencing, spin column-purified (Qiagen, Chatsworth, CA.) DNA fragments were sequenced using a BigDye ${ }^{\mathrm{TM}}$ Terminator v3.1 Cycle Sequencing Kit (Applied Biosystems/ThermoFisher Scientifics, Waltham, MA). Sequencing was conducted using an Applied Biosystems Prism 3100, in a short capillary (47 cm $\times 50$ $\mu \mathrm{m}$ inside diameter), and Performance Optimized Polymer 6 (Perkin-Elmer, Waltham, MA, and Applied Biosystems).

\subsection{Phylogenetic analyses}

The phylogenetic trees for DENV-1, DENV-2, DEl ' V-?, and DENV-4 were inferred using the maximum likelihood method of Tat un. and Nei (1993). For this method the percentage of replicate trees in which \& e a sociated taxa clustered together in the bootstrap test (1,000 replicates) are sho $\mathrm{N}$ r rext to each branch (Felsenstein, 1981). Initial trees for the heuristic sea $n t^{\bullet}$ obtained by applying the neighbourjoining method to a matrix of pairwise diswnces estimated using maximum composite likelihood (MCL) (Tamura et al., $2\left(i^{1}\right)$ A discrete gamma distribution was used to model evolutionary rate differc a ces among sites with 3 rate categories $(+\mathrm{G}$, parameter $=$ 0.2447). The final tree is dra $" n$ to scale, with branch lengths measured by number of substitutions per site. All c jove analyses were performed using MEGA7 (Molecular Evolutionary Genetic Analysis Version 7.0) software (Kumar et al., 2016).

Phylogenetic trees were then constructed using a Markov chain Monte Carlo integration (MCMC)-based Bayesian analys is with the minimum recommended parameters (uncorrelated log-normal relaxed clock, with a GTR substitution model with Gamma 4), implemented in BEAST v1.10.3 software (Suchard et al., 2018). MCL trees and Bayesian trees were compared to assess the extent of congruence between these methods. 
2.7. Absolute percent difference between dengue fever and severe dengue cases in both Veracruz State and Mexico.

The percentage of variation between tandem epidemiologic years was calculated as follows:

$$
\left[\left(\frac{\text { final value }}{\text { initial value }}\right)-1\right] 100
$$

Where final value is the number of cases (either denç de fever or severe dengue) in the year of interest, and initial value is the number of ca es ( ither dengue fever or sever dengue) in the preceding year.

The absolute percent difference between dc. 'ouf fever and severe dengue was calculated as follows:

$$
\left(\frac{\text { first valu }}{(\text { first value }}+\frac{- \text { second value }}{\text { s.cond value }) / 2}\right) 100
$$

Where first value is the nu, re of cases of dengue fever and second value is the number of cases of severe $d \epsilon$ ngu

\section{Results}

3.1. Epidemiology of dengue in Mexico and serotyping of virus isolates

Cases of dengue are widely underreported and moreover, circulating serotype distribution is not well established, creating a need for a broader and more nuanced understanding (Gómez-Dantés and Willoquet, 2009). Figure 1 shows dengue and severe dengue incidence increase in Mexico between 1990 and 2019. The percentage of variation in number of dengue fever versus severe dengue cases in both Veracruz and 
Mexico was calculated to assess spatiotemporal dengue patterns. Although percentage of variation generally fluctuates between each epidemiological year, according to Figure 2A, the rate of increase was greater from 2001 to 2002, 2003 to 2004 and 2011 to 2012 compared with other years. Figure 2B depicts the absolute percentage difference of dengue fever to severe dengue cases between 1990 and 2019 in both Veracruz State and Mexico. The relative percentage of severe dengue cases has increased compared to dengue fever cases in both Veracruz State and Mexico. The 2009 incidence of dengue fever was greatest in Veracruz compared to any other State in th country, evidence of the devastating effects of Hurricane Ida on mosquito-bo'^e iluness within a geographic area (DREF, 2009). If we compare the absolute percent oe difference (proportion) in dengue fever versus severe dengue cases between $V t_{2}{ }^{7}$ cruz and Mexico (Figure 2B), the percentage difference remained similar 'se. ver,n 1990 and 2000, followed by an increase in the percentage difference, rer.ter sever dengue) beginning in 2000-2001 in Mexico, and 2003-2004 in Veracruz. Between 2007 and 2008 there is a sharp increase in the proportion of severe denme ' $:$ 'es in Veracruz that continues until 2009. In 2008 and 2014 there was a conspi lous dissonance in the proportion of severe dengue to dengue fever cases in Vera ${ }^{-r r} z$ compared to Mexico. Both years exhibited a noticeable increase in severe dt. rut in Veracruz, separated by a sizeable recovery in 2010 . The proportion of dengue fever to severe dengue cases in Veracruz compared to Mexico was very similar in the years 2004-2007, 2011-2012, and 2015-2017.

\subsection{Isolation and serotyping of DENV}

All samples were evaluated using the Mac-Elisa test, which is standard protocol of the Mexican Ministry of Health for diagnosing DENV infections (Cisneros-Solano et al., 2004). Patients whose clinical reports showed symptoms of severe dengue had laboratory results verified using an IgG-ELISA kit. Serotyping was performed via RT- 
PCR using the RNA obtained from isolates in C6/36 cells and repeated at least twice. Out of 215 isolates from Oaxaca, 31 were diagnosed with severe dengue- $74.5 \%$ were DENV-2, 6.4\% were DENV-3, 6.4\% were DENV-4, $4.2 \%$ were DENV-1, and $8.5 \%$ presented dual infections (DENV-2 with either DENV-1, -3, or -4).

\subsection{Phylogenetic analysis of Veracruz isolates}

Portions of the C139-prM789 or NS3-484 gene were amplified and sequenced as described in the Methods section. Fifteen sequences were ob - ined from the Veracruz 2009 isolates for the C-prM fragment (eight with dengue ft ver ind eight with severe dengue) and seven sequences for the NS3 gene (all wi h gue fever). Five sequences from the 2005 outbreak in Oaxaca were added, tw of he DENV-2 Asian/American genotype and 3 of DENV-3, genotype III. $\mathrm{Ph}_{1} \mathrm{IO}_{2}^{\prime}$ enetic analyses were performed on the aforementioned sequences and furtherm $J 1$ pintotype sequences of characterized isolates for DENV-1, -2, -3, and -4 (Domı.zuez-de-la-Cruz et al., 2020). Eleven

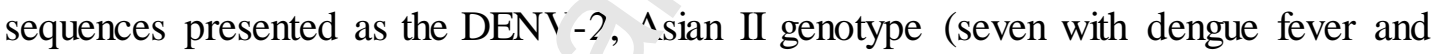
seven with severe dengue), th 1 a presented as the DENV-2 Asian/American genotype (all with dengue fever), and v vo presented as DENV-4, genotype I (one with dengue fever and one coinfect d v ith DENV-2 Asian II genotype with severe dengue).

Genotypes I and II war ‘ assessed for DENV-1 and -3 using the NS3 gene (Domínguezde-la-Cruz et al., 2020).

Phylogenetic analyses showed that C139-prM789 (Asian/American genotype) from Veracruz was most closely related to dengue strains from Oaxaca and Veracruz during the 2005 and 2006 outbreaks. Strains were closely related to those previously found in the Caribbean countries of Cuba, the Dominican Republic (DR), and Martinique (Mar) (France) (Domínguez-de-la-Cruz et al., 2020) (Figure 3). Strains from these regions were all grouped on the same branch of the constructed phylogenetic tree 
(Figure 3). DENV-2 isolates from Veracruz (Asian II genotype) were most closely related to strains from Colombia and Thailand (Figure 3). DENV strains from Brazil, Venezuela and Jamaica formed an independent clade. Interestingly, analys is of C139prM789 showed that isolates obtained in 2001 from Juchitán, Tonalá, Tuxtepec, Huatulco, and Salina Cruz, Oaxaca State shared the same clade as strains from Venezuela, Puerto Rico (USA), and Taiwan (Taiw) for the Asian/American genotype. A shorter fragment of the gene for the prM protein, including isolates from Guerrero State, Mexico (Asian II genotype) showed that isolates from Verarriz helonged to the same phylogenetic tree branch. This finding confirms the circ sai in of the DENV-2, Asian II genotype in Veracruz State (Domínguez-de-la-Cruz et .' 1,2020$).$

Phylogenetic analyses using C139-prM78', sequences revealed that both DENV4 isolates from the 2009 dengue epidemic $\therefore$ Veracruz, Mexico present as genotype I, and are most closely related to strains th $\eta$ Philippines and China (Figure 4). Moreover, both isolates share a close evolutionary lineage with strains from the Amazonas State, Brazil (Figure 5). Notably, ger sty $y^{\circ}$ I was not previously reported in Mexico. DENV-4 trees were constructed with st: 1 lences of 567 bp (Figure 4) and 363 bp (Figure 5) because Brazilian seq' en 2 sere relatively shorter. DENV-4, genotype II, which has been previously reports $d$ in the Americas was not identified in this study (Bennett et al., 2003). Phylogenetic analyses using the NS3-484 gene showed that DENV-1 isolates presented as genotype $\mathrm{V}$, and that they are most closely related to strains from Puerto Rico (USA) and Brazil. This particular genotype has been circulating in the Americas since approximately 2004 (Domínguez-de-la-Cruz et al., 2020). Phylogenetic analyses using the NS3-484 gene showed that DENV-3 isolates presented as genotype III, and that they share an affinity with strains from the 2005 dengue epidemic in Oaxaca. Such 
genotypes have been circulating in the Americas since approximately 2001 (Domínguez-de-la-Cruz et al., 2020).

MCL trees were compared with Bayesian trees to assess the extent of congruence between these methods. Our results found that the topology of resultant trees was very similar. Bayesian analyses confirm the presentation of the Asian II genotype of DENV-2 (Domínguez-de-la-Cruz et al., 2020) and genotype I of DENV-4, in Veracruz (Figure 5).

\section{Discussion}

After broad campaigns between 1947 and 197u by the Pan American Health Organization (PAHO) to eradicate Ae. aegv tt in tropical and subtropical America, yellow fever and dengue were largely, . $h$, ugh temporarily, eliminated (Brathwaite-Dick et al., 2012). Arbovirus surveillance $\epsilon$ 'antually waned, leading to a rapid and widespread re-emergence of $A \ldots e_{\text {¿y }} p t i$ in environmentally suitable countries. An outbreak of DENV-1 infectio. occurred in Mexico in 1978. In 1984, eight DENV-4 severe dengue cases $\mathrm{w}_{\text {r. }}$ rorted, resulting in four deaths. By 1989, four more DENV4 severe dengue cases vere reported, resulting in 1 death, and in 1991, two more cases were reported. The emergence of DENV-2 in Mexico occurred in 1981 (30,000 cases) and was followed shortly thereafter by another outbreak in 1984 (23,000 cases). DENV1, -2, and -4 were isolated by in 1994, and DENV-3 was first reported in Mexico in 1995 (Brathwaite-Dick et al., 2012). By 1997, all four serotypes of DENV were circulating in Mexico (Gardella-Garcia et al., 2008).

Phylogenetic analyses of DENV-1 and DENV-3 displayed the presentation of genotypes V and III, respectively, despite clustering with different clades. This is 
suggestive of viral evolution. The DENV-2 Asian/American genotype has slowly replaced the American genotype. The geographic origin of the Asian/American genotype strain in Veracruz may have been introduced from nearby Caribbean islands. The DENV-2, Asian II genotype was identified in dengue fever (63.6\%) and severe dengue (36.4\%) cases. Strains isolated in the years 1983, 1984, 1992, 1994, and 1995 were identified as the American genotype. One 1996 isolate from Yucatán State was dubbed the "Cosmopolitan" genotype by Loroño-Pino et al. (2004). Mexican DENV-2 isolates from Yucatán and Oaxaca between 2000 and 2002, ana 7axaca and Veracruz between 2005 and 2006 have previously been reported $J u \cdot$ long the Asian/American genotype (Díaz et al., 2006; Gardella-Garcia et al, 20u?).

This study provides evidence for the intraciuction of the Asian II genotype of DENV-2, in Mexico during the 2009 Verac $\mathrm{lZ}$ aengue outbreak. The Asian II genotype was first reported in Mexico in two DE $\mathrm{V}$-2 isolates from 1997 in Guerrero, Mexico (GenBank accession number: AY4196,9, AY449679). According to phylogenetic analyses, this strain is closely ela ${ }^{\circ}$ a with DENV-2 strains collected from Cuba in 1981 (Rodriguez-Roche et al., 211), (GenBank accession number: EU854293), and later Colombia (GenBank /.ccission Number: EU854293) and Asia (GenBank Accession Number: AF204178 an 1 AF204177) (Domínguez-de-la-Cruz et al., 2020). The geographic origin of the Mexican DENV-2, Asian II genotype may be Guerrero State and/or the Caribbean islands. This study has also described the introduction of DENV-4 genotype II, previously reported in Manaus, Brazil in 2008 (de Melo et al., 2009; Figueiredo et al., 2008; ). Although DENV-4 is less prevalent than other dengue serotypes in Mexico, it has been shown to be involved in the development of severe dengue following secondary infections, and hence of significant epidemiological importance (Ahamed et al., 2019; Guo et al., 2017; Soo et al., 2016; Suppiah et al., 
2018). This study identified two DENV-4, genotype II isolates, one from a patient coinfected with DENV-3, genotype III, and diagnosed with severe dengue.

The increased frequency of severe dengue in Veracruz coincides with the permanence of the DENV-2 Asian/American genotype and the emergence of both the DENV-2, Asian II genotype, and DENV-4, genotype I. The DENV-2, Asian II genotype, and DENV-4, genotype I have been reported in Acapulco and Chilpancingo, Mexico, as well as Brazil (Kubiszeski et al., 2020; de Melo $r t$ al., 2009; Figueiredo et al., 2008). The novel genotypic/lineage variations in DEN -2 nd DENV-4 may have influenced the magnitude and severity of Veracruz dens le $\epsilon$ pidemics in 2009 , since the severe dengue patients were infected by the novel ${ }^{\top} \mathrm{E}^{\top} \downarrow-2$ Asian II genotype. This suggests that these particular genotypes cause moie severe disease directly (Figure 2B). Prior studies have shown the potential for 1 . vel genotypic/lineage variations to have epidemiological affects (Ahamed et al., : n19; De La Cruz-Hernández et al., 2013; Gardella-Garcia et al., 2008; Zhanc, et '., 2005). Relative increases in severe dengue cases in particular may be due 0 , he circulation of specific genotypes during certain years that cause an increasc in tengue infection severity and incidence. Once the infection caused by th $\iota s_{1}$ ecific genotype passes through the population, herd immunity is achieved, reducing $\mathrm{t}_{2} 2$ incidence of infection. If a different, novel genotype begins to circulate, however, it will re-infect the population, generating another spike in either incidence, disease severity, or both (OhAinle et al., 2011; Cologna et al., 2005; Hang et al., 2010).

Apart from direct host-, vector-, and virus-related determinants, ecological factors such as climatic variation (i.e. seasonality), and weather events (i.e. flooding, hurricanes, etc.) are integral to the fitness and ultimate distribution of both dengue vectors and novel DENV strains. Our results show that increases in dengue fever and 
severe dengue cases overlapped with the climatological and infrastructural fallout of Hurricane Ida in 2009. Hurricanes in Veracruz in 2007 (Hurricane Dean) and 2012 (Hurricane Ernesto) (CONAGUA, 2019), were also found to coincide with an uptick in severe dengue cases (Figure 2). Although such observations are indeed in agreement with previous reports showing a causative association between severe hurricane years and arbovirus infection rates, further statistical analyses will have to be conducted before drawing any conclusions regarding the data from this study in particular (Messina et al., 2015; Morin et al., 2013). A future synthesis ot Jemographic, sociocultural, ecological and infrastructural elements will volutionary virology is paramount to further elucidating dengue epidemioloov in the Americas.

\section{Conclusions}

In 2009, Veracruz State was affected $b$, tel ${ }^{2}$ rains due to Hurricane Ida, causing flooding and infrastructural damage, leavi.g thousands without homes, and creating an ideal mosquito breeding (DREF, $(2$, '? Ap Aproximately 42,000 cases of dengue infection were confirmed that ,ear in Veracruz, representing a $30 \%$ increase from the previous year (2008). The en argence of novel genotypes is due to an overall increase in dengue cases, leading to a higher probability of genetic divergence. Findings show that the predominant DENI serotypes circulating during this outbreak were: (1) DENV-2, followed by (2) DENV-3, (3) DENV-1, and (4) DENV-4. Five cases of DENV-2, genotype I were coinfected with serotypes $-1,-3$, or -4 . The primary DENV genotypes found in Veracruz during the 2009 epidemic were:
(A) The Asian II and Asian/American genotypes (DENV-2)
(B) Genotype III (DENV-3)
(C) Genotype V (DENV-1) 
(D) Genotype I (DENV-4).

Severe dengue cases were identified mainly in subjects infected with the DENV-2, Asian II genotype, and DENV-4, genotype I. Results suggest a possible association between the emergence of novel DENV genotypes with both an increase in DENV incidence and frequency of severe dengue. To corroborate this potential relationship, annual testing should be conducted in a large sample size every year following the introduction of novel genotypes to a particular geographic region. Routine serological and nucleic acid detection methodologies should be employ ed o this end.

\section{Acknowledgements}

The authors would like to thank Rosalina $a_{a}$ Tovar-Gallegos for her invaluable technical assistance. We are also grateful to $\mathbf{L}$ 'ane J. Gubler and Blanca Ruiz for generously providing control samples. Lactly, ve are obliged to all study participants and anonymous reviewers.

This study was coı nle ad hanks to the generous support of Consejo Nacional de Ciencia y Tecnología, Mexico: EHG (Registration Number: 111110038; CVU: 49406), and ED-de-la-C (CONACYT Registration Number: 280838; CVU: 485179; and COMECYT Scholarship Number: 18BTD0020).

\section{Author Disclosure Statement:}

The authors have no potential conflicts of interest. 


\section{References}

Ahamed, S.F., Rosario, V., Britto, C., Dias, M., Nayak, K., Chandele, A., Kaja, M.K., Shet, A., 2019. Emergence of new genotypes and lineages of dengue viruses during the 2012-15 epidemics in southern India. Int. J. Infect. Dis. 84, S34-S43. doi:10.1016/j.ijid.2019.01.014

Bennett, S.N., Holmes, E.C., Chirivella, M., Rodriguez, D.M., Beltran, M., Vorndam, V., Gubler, D.J., McMillan, W.O., 2003. Selection-drive evolution of emergent dengue virus. Mol. Biol. Evol. 20, 1650-1658. doi:10. ' 09: /molbev/msg182

Brathwaite-Dick, O., San-Martín, J.L., Montoya, R.H., del-Diego, J., Zambrano, B., Dayan, G.H. 2012. The history of dengue outhl iks in the Americas. Am J Trop Med Hyg. 87(4):584- 593. doi:10.4269/; it _nt .2012.11-0770

Cisneros-Solano, A., Moreno-Altamiraı ? M.M.B., Martínez-Soriano, U., JimenezRojas, F., Díaz-Badillo, A., Mun`? M.L., 2004. Sero-epidemiological and Virological Investigation fi Dugue Infection in Oaxaca, Mexico, during 20002001. Dengue Bull. 28, 29-34.

Cisneros, A., Díaz-Ba illo, Á., Cruz-Martínez, G., Tovar, R., Ramírez-Palacios, L.R., Jiménez-Rojas, F. Beaty, B., Black IV, W.C., De Lourdes Muñoz, M., 2006. Dengue 2 genotypes in the state of Oaxaca, Mexico. Arch. Virol. 151, 113-125. doi:10.1007/s00705-005-0595-9

Clyde, K., Kyle, J.L., Harris, E., 2006. Recent Advances in Deciphering Viral and Host Determinants of Dengue Virus Replication and Pathogenesis. J. Virol. 80, 1141811431. doi:10.1128/JVI.01257-06

Cologna, R., Armstrong, P.M., Rico-Hesse, R., 2005. Selection for Virulent Dengue 
Viruses Occurs in Humans and Mosquitoes. J. Virol. 79, 853-859.

doi:10.1128/jvi.79.2.853-859.2005

CONAGUA, 2020. Pronóstico Meteorológico General. Mexico City.

Dantés, H.G., Farfán-Ale, J.A., Sarti, E., 2014. Epidemiological Trends of Dengue Disease in Mexico (2000-2011): A Systematic Literature Search and Analysis. PLoS Negl. Trop. Dis. 8, e3158. doi:10.1371/journal.pntd.0003158

De La Cruz-Hernández, S.I., Flores-Aguilar, H., González-Maı ’s, S., López-Martinez, I., Alpuche-Aranda, C., Ludert, J.E., Del Angel, R. ${ }^{M}$ in 13 . Determination of viremia and concentration of circulating nonstruc. 'ral protein 1 in patients infected with dengue virus in Mexico. Am. J. Trop. Mei ifyg. 88, 446-454. doi:10.4269/ajtmh.12-0023

de Melo, F.L., Romano, C.M., Zanotto, F.M. de A., 2009. Introduction of dengue virus 4 (DENV-4) genotype I into Bra:"1 from Asia? PLoS Negl. Trop. Dis. 3, e390.

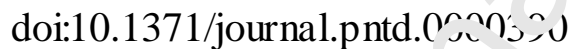

Díaz, F.J., Black IV, W.C., Garıăn-Ale, J.A., Loroño-Pino, M.A., Olson, K.E., Beaty, B.J., 2006. Deng e V rus Circulation and Evolution in Mexico: A Phylogenetic Perspective. Arch. Med. Res. 37, 760-773. doi:10.1016/j.arcmed.2006.02.004

Dirección General de Epidemiología, 2020. Histórico Boletín Epidemiológico | Secretaría de Salud | Gobierno | gob.mx [WWW Document]. URL https://www.gob.mx/salud/acciones-y-programas/historico-boletin-epidemiologico (accessed 4.12.20).

Domínguez-de-la-Cruz E., Muñoz M. de L., Hernández-García E., Pérez-Ramírez G., R.E. David., Navarrete-Espinosa J., Díaz-Badillo A., Moreno-Galeana M., Brito- 
Carreón C.A., 2020. Data set on Epidemiology, and Genetic Diversification of Dengue Virus (DENV) Serotypes and Genotypes in Mexico. Data in Brief. In revision.

DREF, 2009. Mexico: Dengue Outbreak DREF Operation No. MDRMX004 - Mexico | ReliefWeb [WWW Document]. URL https://reliefweb.int/report/mexico/mexicodengue-outbreak-dref-operation- no-mdrmx004 (accessed 9.12.19).

Falcón-Lezama, J., Sánchez-Burgos, G.G., Ramos-Castañeda. J., 2009. [Population genetics of dengue virus and transmission of dengue t'ver Salud Publica Mex. 51 Suppl 3, S403-9.

Felsenstein, J., 1981. Evolutionary trees from DNA _ yuences: A maximum likelihood approach. J Mol Evol 17, 368-376. doi:1 1 10 77/BF01734359

Figueiredo, R.M.P. de, Naveca, F.G., L’ ,os, M. de S., Melo, M. do N., Viana, S. de S., Mourão, M.P.G., Costa, C.A. Fa.'ias, I.P., 2008. Dengue virus type 4, Manaus, Brazil. Emerg. Infect. Dis :1, ú7-9. doi:10.3201/eid1404.071185

Gardella-Garcia, C.E., Pert:-Kamirez, G., Navarrete-Espinosa, J., Cisneros, A., Jimenez-Rojas, F., R، mírez-Palacios, L.R., Rosado-Leon, R., Camacho-Nuez, M., Munoz, M.D.L. 2 J08. Specific genetic markers for detecting subtypes of dengue virus serotype- 2 in isolates from the states of Oaxaca and Veracruz, Mexico. BMC Microbiol. 8, 117. doi:10.1186/1471-2180-8-117

Gómez-Dantés, H.,, Willoquet, J.R., 2009. Dengue in the Americas: challenges for prevention and control. Cad Saude Publica. 25 Suppl 1:S19-31. doi: $10.1590 / \mathrm{s} 0102-311 \times 2009001300003$

Gubler, D., 1998. The global pandemic of dengue/dengue haemorrhagic fever: current 
status and prospects for the future. Ann. Acad. Med. Singapore 27, 227-34.

Gubler, D.J., 2004. The changing epidemiology of yellow fever and dengue, 1900 to 2003: full circle? Comp. Immunol. Microbiol. Infect. Dis. 27, 319-30. doi:10.1016/j.cimid.2004.03.013

Guo, C., Zhou, Z., Wen, Z., Liu, Y., Zeng, C., Xiao, D., Ou, M., Han, Y., Huang, S., Liu, D., Ye, X., Zou, X., Wu, J., Wang, H., Zeng, E.Y., Jing, C., Yang, G., 2017. Global epidemiology of dengue outbreaks in 1990-201: A systematic review and meta-analysis. Front. Cell. Infect. Microbiol. 7, 317. c >i:11 .3389/fcimb.2017.00317

Hang, V.T.T., Holmes, E.C., Veasna, D., Quy, N.T., 1.en, T.T., Quail, M., Churcher, C., Parkhill, J., Cardosa, J., Farrar, J., Wills, B., 'ennon, N.J., Birren, B.W., Buchy, P., Henn, M.R., Simmons, C.P , 'r,11. Emergence of the Asian 1 genotype of dengue Virus serotype 2 in vif $\mathrm{N}$.m: in vivo fitness advantage and lineage replacement in South-East Ası PLoS Negl. Trop. Dis. 4. doi:10.1371/journal.pntd.000J 5

Huy, N.T., Van Giang, T., Tı.v, D.H.D., Kikuchi, M., Hien, T.T., Zamora, J., Hirayama, K., 201ュ tuctors Associated with Dengue Shock Syndrome: A Systematic Revie.' and Meta-Analysis. PLoS Negl. Trop. Dis. 7, e2412. doi:10.1371/journal.pntd.0002412

Istúriz, R.E., Gubler, D.J., Brea del Castillo, J., 2000. Dengue and dengue hemorrhagic fever in Latin America and the Caribbean. Infect. Dis. Clin. North Am. 14, 12140, ix.

Kochel, T.J., Watts, D.M., Halstead, S.B., Hayes, C.G., Espinoza, A., Felices, V., Caceda, R., Bautista, C.T., Montoya, Y., Douglas, S., Russell, K.L., 2002. Effect of dengue- 1 antibodies on American dengue-2 viral infection and dengue 
haemorrhagic fever. Lancet 360, 310-312. doi:10.1016/S0140-6736(02)09522-3

Kumar, S., Stecher, G., Tamura, K., 2016. Kumar, S., Stecher, G., \& Tamura, K. (2016). MEGA7: Molecular Evolutionary Genetics Analysis version 7.0 for bigger datasets. Mol. Biol. Evol. 33, 1870-1874. doi:10.1093/molbev/msw054

Kubiszeski, J.R., Carla Julia da Silva Pessoa Vieira, Sirlei Franck Thies, David José Ferreira da Silva, Eriana Serpa Barreto, Adriano Mondini, and Roberta Vieria de Morais Bronzoni. 2020. Detection of the Asian II genoty e of dengue virus serotype 2 in humans and mosquitoes in Brazil. Rev. 'oc. 3ras. Med. Trop. 53 Uberaba 2020. doi:101590/0037-8682-0439-201!

Loroño-Pino, M.A., Farfán-Ale, J.A., Zapata-Peraza, ‘.L., Rosado-Paredes, E.P., Flores-Flores, L.F., García-Rejón, J.E.. Iªz, F.J., Blitvich, B.J., Andrade-Narváez, M., Jiménez-Ríos, E., Blair, C.D . O' ,on, K.E., Black IV, W., Beaty, B.J., 2004. Introduction of the American/s ian genotype of dengue 2 virus into the Yucatán State of Mexico. Am. J. Trop. M zd. Hyg. 71, 485-492. doi:10.4269/ajtmh.2004 71. 95

Loroño-Pino, M.A., F.sin isle, J.A., Rosado Paredes, E.P., Kuno, G., Gubler, D.J., 1993. Epidemic ¿'ngue 4 in the Yucatán, México, 1984. Rev. Inst. Med. Trop. Sao Paulo 35, 449-455. doi:10.1590/S0036-46651993000500011

Mercado-Reyes, M., Acosta-Reyes, J., Navarro-Lechuga, E., Corchuelo, S., Rico, A., Parra, E., Tolosa, N., Pardo, L., González, M., Martìn-Rodriguez-Hernández, J., Karime-Osorio, L., Ospina-Martinez, M., Rodriguez-Perea, H., Del Rio-Pertuz, G., Viasus, D., 2019. Dengue, chikungunya and zika virus coinfection: results of the national surveillance during the zika epidemic in Colombia. Epidemiol. Infect. 147, e77. doi:10.1017/S095026881800359X 
Messina, J.P., Brady, O.J., Pigott, D.M., Golding, N., Kraemer, M.U.G., Scott, T.W., Wint, G.R.W., Smith, D.L., Hay, S.I., 2015. The many projected futures of dengue. Nat. Rev. Microbiol. doi:10.1038/nrmicro3430

Moore, M., Sylla, M., Goss, L., Burugu, M.W., Sang, R., Kamau, L.W., Kenya, E.U., Bosio, C., Munoz, M. de L., Sharakova, M., Black, W.C., 2013. Dual African origins of global Aedes aegypti s.l. populations revealed by mitochondrial DNA. PLoS Negl. Trop. Dis. 7, e2175. doi:10.1371/journal.pn+d.0002175

Morin, C.W., Comrie, A.C., Ernst, K., 2013. Climate and c 'ng z transmission: Evidence and implications. Environ. Health Persiec.. „oi:10.1289/ehp.1306556

Murray, N.E.A., Quam, M.B., Wilder-Smith, A., 2v: ?. Epidemiology of dengue: past, present and future prospects. Clin. Epide rol 5, 299-309. doi:10.2147/CLEP.S34440

OhAinle, M., Balmaseda, A., Macalak``. A.R., Tellez, Y., Zody, M.C., Saborío, S.,

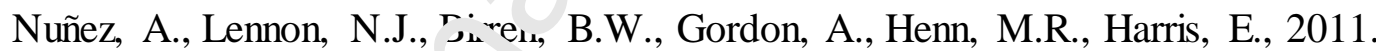
Dynamics of dengue disu se severity determined by the interplay between viral

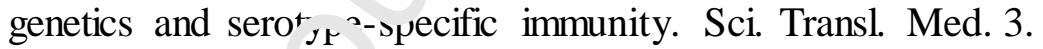
doi:10.1126/scitra. 'slmed.3003084

Pinheiro, F.P., Corber, S.J., 1997. Global situation of dengue and dengue haemorrhagic fever, and its emergence in the Americas. World Heal. Stat. Q. 1997 ; 50(3/4) 161169.

Rico-Hesse, R., Harrison, L.M., Salas, R.A., Tovar, D., Nisalak, A., Ramos, C., Boshell, J., de Mesa, M.T., Nogueira, R.M., da Rosa, A.T., 1997. Origins of dengue type 2 viruses associated with increased pathogenicity in the Americas. Virology 230, 244-51. doi:10.1006/viro.1997.8504 
Rodriguez-Roche, R., Gould, E.A., 2013. Understanding the Dengue Viruses and Progress towards Their Control. Biomed Res. Int. 2013, 20. doi:10.1155/2013/690835

Ryan, S.J., Carlson, C.J., Mordecai, E.A., Johnson, L.R., 2018. Global expansion and redistribution of Aedes-borne virus transmission risk with climate change. PLoS Negl. Trop. Dis. 13, e0007213. doi:10.1371/journal.pntd.0007213

Seah, C.L.K., Chow, V.T.K., Tan, H.C., Chan, Y.C., 1995. Rapid, single-step RT-PCR typing of dengue viruses using five NS3 gene primers. V. Virol. Methods 51, 193200. doi:10.1016/0166-0934(94)00104-O

Soo, K.M., Khalid, B., Ching, S.M., Chee, H.Y., 201^ Murd-analysis of dengue severity during infection by different dengue :

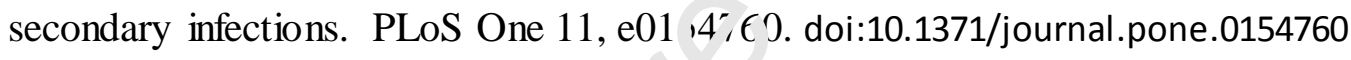

Suchard, M.A., Lemey, P., Baele, G., Ayss, D.L., Drummond, A.J., Rambaut, A., 2018. Bayesian phylogenetic an ${ }^{1}$ phylodynamic data integration using BEAST 1.10. Virus Evol. 4, vey016 d i.10.1093/ve/vey016

Suppiah, J., Ching, S.M., ^ mı. Nordin, S., Mat-Nor, L.A., Ahmad-Najimudin, N.A., Low, G.K.K., At uu Wahid, M.Z., Thayan, R., Chee, H.Y., 2018. Clinical manifestations of lengue in relation to dengue serotype and genotype in Malaysia: A retrospective observational study. PLoS Negl. Trop. Dis. 12, e0006817. doi:10.1371/journal.pntd.0006817

Tamura, K., Nei, M., 1993. Estimation of the number of nucleotide substitutions in the control region of mitochondrial DNA in humans and chimpanzees. Mol. Biol. Evol. 10, 512-26. doi:10.1093/oxford journals.molbev.a040023

Tamura, K., Nei, M., Kumar, S., 2004. Prospects for Inferring Very Large Phylogenies 
by Using the Neighbor-Joining Method. Proc Natl Acad Sci U S A. 101(30), 11030-5. doi: 10.1073/pnas.0404206101

Torres-Galicia, I., Cortés-Poza, D., Becker, I., 2014. Dengue in Mexico: Increase in the juvenile population during the last decade. Bol. Med. Hosp. Infant. Mex. 71, 196201. doi:10.1016/j.bmhimx.2014.08.003

Zhang, C., Jr, M.P.M., Klungthong, C., Monkongdee, P., Nimmannitya, S., Kalayanarooj, S., Holmes, E.C., Mammen, M.P., Chinna sirotpisan, P., Rodpradit, P., 2005. Clade Replacements in Dengue Virus Seroty nes $L$ and 3 Are Associated with Changing Serotype Prevalence Clade Replac en..n.s in Dengue Virus Serotypes 1 and 3 Are Associated with Chans $7 g$;erotype Prevalence $\uparrow$. J. Virol. 79, 15123-15130. doi:10.1128/JVI.79.24.1-123

\section{Figure Legends}

Figure 1. Dengue virus incidence in Veracruz State and Mexico. Reported incidence (Annual new cases per $100,00 \mathrm{~S}$ - dividuals) of dengue fever and the proportion of severe dengue cases across v racruz State and Mexico between 1990 and 2019

Figure 2. (A) Numbe $\cdot$ ot ases and percentage of variation of dengue fever and severe dengue betwee 11990 and 2019, and (B) Absolute percentage differences between dengue fever and severe dengue cases between 1990 and 2019 in both Veracruz State and Mexico. (A) The total number of cases of dengue fever and severe dengue in Veracruz State and Mexico is displayed in bars and the percentage of variation in lines. D-MEX and D-VER represent dengue cases from Mexico and Veracruz, respectively; SD-MEX and SD-VER represent severe dengue cases from Mexico and Veracruz, respectively. (B) Displays the absolute percentage difference between the number of cases of dengue fever and severe dengue in both Veracruz State 
and Mexico between 1990 and 2019, according to the formula described in the Material and Methods section. Lower values represent a higher proportion of severe dengue. Table 1 displays all corresponding, graphed values.

\section{Figure 3. Maximum-likelihood phylogenetic tree of 150 DENV-2 CpM gene} sequences (380 nucleotides). The midpoint rooted phylogenetic tree includes 13 new sequences in Asian/American and Asian II genotypes, labelled in bold. All samples are from the State of Veracruz, Mexico. The phylogenetic tree vas obtained using MEGA 7 as described in the section of Methods. The percentages of iepi zate trees in which the associated taxa clustered together in the bootstrap test (..001 replicates) are shown next to branches. Positions of sequences from Mexico a e w divated using a dot, from the Americas using a triangle, and novel sequences from Veracruz State in bold. Horizontal branch lengths are proportional to the bar $\mathrm{r}$ - vresenting number of nucleotide substitutions/sites. MX: Mexico; MZ/O; X: Mexico, Oaxaca; MX/VER: Mexico, Veracruz; US/PR: United States, Pren Rico; VE: Venezuela; NI: Nicaragua; COL: Colombia; EC: Ecuador; BR: I, $\mathrm{ra}_{e}^{-i}$; Ph, Philippines; China, Chin. DENV strains are named as follows: GenBan' à ession number/strain/country/year/serotype/genotype (Domínguez-de-la-Crv $\angle \iota^{+}$al., 2020).

\section{Figure 4. Maximum l'icelihood phylogenetic tree of 150 DENV-4 CprM gene} sequences (567 nucleotides). Details of phylogenetic tree analysis and graphical features are the same as those provided in the Figure 3 legend. This phylogenetic tree includes two novel sequences of genotype I, labelled in bold. Positions of sequences from Mexico are indicated using a dot, from the Americas using a triangle, and novel sequences from Veracruz State in bold. MX: Mexico; MZ/OAX: Mexico, Oaxaca; MX/VER: Mexico, Veracruz; US/PR: United States, Puerto Rico; VE: Venezuela; NI: Nicaragua; COL: Colombia; EC: Ecuador; BR: Brazil. 


\section{Figure 5. Maximum clade credibility (MCC) tree of 132 DENV-4 CprM gene} sequences (363 nucleotides). This phylogenetic tree includes two new sequences of genotype I, labeled in bold. Positions of sequences from Mexico are indicated using a dot, and from the Americas using a triangle. Horizontal branch lengths are proportional to the bar representing the probability of coalescence. DENV strains are named as follows (GenBank accession number/serotype/country/year/genotype). MX: Mexico; MZ/OAX: Mexico, Oaxaca; MX/VER: Mexico, Veracruz; US/PR: United States, Puerto Rico; VE: Venezuela; NI: Nicaragua; COL: Colombja L L Ph, Philippines; China, Chin.

\section{Tables}

Table 1. Number of cases and incidence of $d$ ng $d$ f fever/severe dengue in Veracruz State and Mexico between 1990 and 2019. 


\section{Credit author statement:}

M-d-LM conceived and designed research; EHG participated in the elaboration of the project and obtained the isolates; EHG, MM-G, CAB-C, ED-de-la-C performed research; GPR performed the phylogenetic analysis; ED-de-la-Cruz participated in the data analysis and submission of sequences to the GenBank repository; RED, ED-de-la-C, and ADB participated in all data analysis; and M-d-LM wrote the paper; RED participated in the manuscript edition; all authors contributed reviewing and approved the manuscript. 
Table 1. Number of cases and incidence of dengue fever/severe dengue in Veracruz State and Mexico between 1990 and 2019.

\begin{tabular}{|c|c|c|c|c|c|c|c|c|c|c|c|c|}
\hline \multirow[b]{3}{*}{ Year } & \multicolumn{5}{|c|}{ Number of Cases } & & \multicolumn{6}{|c|}{ Incidence (per 100,000) } \\
\hline & \multicolumn{3}{|c|}{ Veracruz State } & \multicolumn{3}{|c|}{ Mexico } & \multicolumn{3}{|c|}{ Veracruz State } & \multicolumn{3}{|c|}{ Mexico } \\
\hline & $\begin{array}{l}\text { Deng } \\
\text { ue } \\
\text { Fever }\end{array}$ & $\begin{array}{l}\text { Seve } \\
\text { re } \\
\text { Deng } \\
\text { ue }\end{array}$ & $\begin{array}{l}\text { Tot } \\
\text { al }\end{array}$ & $\begin{array}{l}\text { Deng } \\
\text { ue } \\
\text { Feve } \\
r\end{array}$ & $\begin{array}{l}\text { Seve } \\
\text { re } \\
\text { Deng } \\
\text { ue }\end{array}$ & $\begin{array}{l}\text { Tot } \\
\text { al }\end{array}$ & $\begin{array}{l}\text { Deng } \\
\text { ue } \\
\text { Feve } \\
\text { r }\end{array}$ & $\begin{array}{l}\text { Seve } \\
\text { re } \\
\text { Deng } \\
\text { ue }\end{array}$ & Tota & $\begin{array}{l}\text { Deng } \\
\text { ue } \\
\text { Feve } \\
r\end{array}$ & $\begin{array}{l}\text { Seve } \\
\text { re } \\
\text { Deng } \\
\text { ue }\end{array}$ & Tota \\
\hline 1990 & 160 & 0 & 160 & 1663 & 6 & $\begin{array}{l}166 \\
9\end{array}$ & 10.71 & 0.00 & $\begin{array}{l}10.7 \\
1\end{array}$ & 11.09 & 0.00 & $\begin{array}{l}11.0 \\
9\end{array}$ \\
\hline 1991 & 143 & 0 & 143 & 1931 & 1 & $\begin{array}{l}193 \\
2\end{array}$ & 4.43 & 0.00 & 4.43 & 6.72 & 0.00 & 6.72 \\
\hline 1992 & 32 & 0 & 32 & 1102 & 0 & $\begin{array}{l}110 \\
2\end{array}$ & 4.86 & 0.00 & 4.86 & 13.74 & 0.00 & $\begin{array}{l}13.7 \\
4\end{array}$ \\
\hline 1993 & 166 & 0 & 166 & 791 & 0 & 791 & 6.87 & $0.0 \mathrm{C}$ & 6.87 & 3.28 & 0.00 & 3.28 \\
\hline 1994 & 2462 & 0 & $\begin{array}{l}246 \\
2\end{array}$ & 7868 & 0 & $\begin{array}{l}786 \\
8\end{array}$ & 37.44 & 0.07 & $\begin{array}{l}37.5 \\
1\end{array}$ & 8.95 & 0.03 & 8.98 \\
\hline 1995 & 5503 & 79 & $\begin{array}{l}558 \\
2\end{array}$ & $\begin{array}{l}1439 \\
6\end{array}$ & 355 & $\begin{array}{l}147 \\
51\end{array}$ & 99.68 & $1 .: \overline{7}$ & $\begin{array}{l}100 . \\
82\end{array}$ & 39.33 & 0.59 & $\begin{array}{l}39.9 \\
2\end{array}$ \\
\hline 1996 & 5297 & 358 & $\begin{array}{l}565 \\
5\end{array}$ & $\begin{array}{l}1983 \\
5\end{array}$ & & $\begin{array}{l}207 \\
19\end{array}$ & $\begin{array}{l}105.2 \\
2\end{array}$ & 7.2 & $\begin{array}{l}112 . \\
49\end{array}$ & 37.62 & 1.56 & $\begin{array}{l}39.1 \\
8\end{array}$ \\
\hline 1997 & 10563 & 155 & $\begin{array}{l}107 \\
18\end{array}$ & $\begin{array}{l}5102 \\
1\end{array}$ & & $\begin{array}{l}519 \\
75\end{array}$ & $\overline{15 n ?}$ & $? .2$ & $\begin{array}{l}152 . \\
4\end{array}$ & 55.48 & 1.03 & $\begin{array}{l}56.5 \\
1\end{array}$ \\
\hline 1998 & 2147 & 28 & $\begin{array}{l}217 \\
5\end{array}$ & $\begin{array}{l}1518 \\
1\end{array}$ & & $\begin{array}{l}154 \\
06\end{array}$ & $\overline{3} 3 . \bar{n}$ & 0.6 & $\begin{array}{l}34.2 \\
6\end{array}$ & 24.17 & 0.39 & $\begin{array}{l}24.5 \\
6\end{array}$ \\
\hline 1999 & 2331 & 10 & $\begin{array}{l}234 \\
1\end{array}$ & $\begin{array}{l}2372 \\
5\end{array}$ & 220 & $\begin{array}{l}2 ? 9 \\
15\end{array}$ & 32.7 & 0.2 & 32.9 & 23.4 & 0.2 & 23.6 \\
\hline 2000 & 568 & 7 & 575 & 1706 & 50 & $\begin{array}{l}75 \\
6\end{array}$ & 8.02 & 0.11 & 8.13 & 1.72 & 0.07 & 1.79 \\
\hline 2001 & 2344 & 14 & $\begin{array}{l}235 \\
8\end{array}$ & 4643 & $\overline{3}, \overline{7}$ & $\begin{array}{l}495 \\
5\end{array}$ & 31.35 & 0.2 & $\begin{array}{l}31.5 \\
5\end{array}$ & 4.6 & 0.31 & 4.91 \\
\hline 2002 & 2357 & 98 & $\begin{array}{l}245 \\
5\end{array}$ & $\begin{array}{l}1313 \\
1\end{array}$ & 7159 & $\begin{array}{l}152 \\
90\end{array}$ & 32.71 & 1.36 & $\begin{array}{l}34.0 \\
7\end{array}$ & 12.95 & 2.11 & $\begin{array}{l}15.0 \\
6\end{array}$ \\
\hline 2003 & 988 & 95 & $\begin{array}{l}108 \\
3\end{array}$ & $\overline{501 \varepsilon}$ & $1 \% 9$ & $\begin{array}{l}643 \\
7\end{array}$ & 14.95 & 3.05 & 18 & 5.01 & 1.7 & 6.71 \\
\hline 2004 & 4250 & 1570 & $\begin{array}{l}582 \\
0\end{array}$ & $\overline{6} .53$ & 1959 & $\begin{array}{l}820 \\
2\end{array}$ & 58.42 & 21.58 & 80 & 5.93 & 1.86 & 7.79 \\
\hline 2005 & 3901 & 636 & $\begin{array}{l}453 \\
7\end{array}$ & $\begin{array}{l}748 \\
7\end{array}$ & 4418 & $\begin{array}{l}219 \\
05\end{array}$ & 53.47 & 8.72 & $\begin{array}{l}62.1 \\
9\end{array}$ & 16.43 & 4.15 & $\begin{array}{l}20.5 \\
8\end{array}$ \\
\hline 2006 & 7265 & 1066 & $\begin{array}{l}80 \\
1\end{array}$ & $\begin{array}{l}256 \\
6\end{array}$ & 4426 & $\begin{array}{l}269 \\
92\end{array}$ & 95.57 & 21.13 & $\begin{array}{l}116 . \\
7\end{array}$ & 22.94 & 4.81 & $\begin{array}{l}27.7 \\
5\end{array}$ \\
\hline 2007 & 12608 & $26 \cdot 5$ & $\begin{array}{l}152 \\
53\end{array}$ & $\begin{array}{l}4293 \\
6\end{array}$ & 9433 & $\begin{array}{l}523 \\
69\end{array}$ & $\begin{array}{l}174.0 \\
9\end{array}$ & 36.52 & $\begin{array}{l}210 . \\
61\end{array}$ & 40.59 & 8.92 & $\begin{array}{l}49.5 \\
1\end{array}$ \\
\hline 2008 & 2066 & 2051 & $\begin{array}{l}711 \\
7\end{array}$ & $\begin{array}{l}2796 \\
4\end{array}$ & 7560 & $\begin{array}{l}355 \\
24\end{array}$ & 28.49 & 28.37 & $\begin{array}{l}56.8 \\
6\end{array}$ & 26.26 & 7.11 & $\begin{array}{l}33.3 \\
7\end{array}$ \\
\hline 2009 & 3412 & 2978 & $\begin{array}{l}639 \\
0\end{array}$ & $\begin{array}{l}4456 \\
5\end{array}$ & $\begin{array}{l}1139 \\
6\end{array}$ & $\begin{array}{l}559 \\
61\end{array}$ & $\begin{array}{l}136.0 \\
8\end{array}$ & 40.91 & $\begin{array}{l}176 . \\
99\end{array}$ & $\begin{array}{l}112.1 \\
8\end{array}$ & 10.6 & $\begin{array}{l}122 . \\
78\end{array}$ \\
\hline 2010 & 867 & 302 & $\begin{array}{l}116 \\
9\end{array}$ & $\begin{array}{l}2235 \\
2\end{array}$ & 9336 & $\begin{array}{l}316 \\
88\end{array}$ & 13.76 & 4.4 & $\begin{array}{l}18.1 \\
6\end{array}$ & 33.89 & 6.18 & $\begin{array}{l}40.0 \\
7\end{array}$ \\
\hline 2011 & 996 & 651 & $\begin{array}{l}164 \\
7\end{array}$ & $\begin{array}{l}1097 \\
0\end{array}$ & 4608 & $\begin{array}{l}155 \\
78\end{array}$ & 17.2 & 11.04 & $\begin{array}{l}28.2 \\
4\end{array}$ & 14.12 & 5.88 & 20 \\
\hline 2012 & 7531 & 5041 & $\begin{array}{l}125 \\
72 \\
\end{array}$ & $\begin{array}{l}3266 \\
2\end{array}$ & $\begin{array}{l}1770 \\
6\end{array}$ & $\begin{array}{l}503 \\
68\end{array}$ & $\begin{array}{l}193.1 \\
5\end{array}$ & 69.82 & $\begin{array}{l}262 . \\
97\end{array}$ & 56.37 & 16.01 & $\begin{array}{l}72.3 \\
8\end{array}$ \\
\hline 2013 & 4941 & 3858 & $\begin{array}{l}879 \\
9\end{array}$ & $\begin{array}{l}4366 \\
3\end{array}$ & $\begin{array}{l}1866 \\
7\end{array}$ & $\begin{array}{l}623 \\
30\end{array}$ & 62.47 & 48.78 & $\begin{array}{l}111 . \\
25\end{array}$ & 89.51 & 16.74 & $\begin{array}{l}106 . \\
25\end{array}$ \\
\hline 2014 & 2060 & 1866 & $\begin{array}{l}392 \\
6\end{array}$ & $\begin{array}{l}2337 \\
4\end{array}$ & 8647 & $\begin{array}{l}320 \\
21\end{array}$ & 25.8 & 23.37 & $\begin{array}{l}49.1 \\
7\end{array}$ & 19.51 & 7.22 & $\begin{array}{l}26.7 \\
3\end{array}$ \\
\hline 2015 & 2884 & 876 & $\begin{array}{l}376 \\
0\end{array}$ & $\begin{array}{l}2120 \\
1\end{array}$ & 5464 & $\begin{array}{l}266 \\
65\end{array}$ & 35.84 & 10.89 & $\begin{array}{l}46.7 \\
3\end{array}$ & 17.52 & 4.52 & $\begin{array}{l}22.0 \\
4\end{array}$ \\
\hline 2016 & 1833 & 391 & $\begin{array}{l}222 \\
4\end{array}$ & $\begin{array}{l}1411 \\
2\end{array}$ & 3683 & $\begin{array}{l}177 \\
95\end{array}$ & 22.61 & 8.64 & $\begin{array}{l}31.2 \\
5\end{array}$ & 11.54 & 3.1 & $\begin{array}{l}14.6 \\
4\end{array}$ \\
\hline 2017 & 1031 & 324 & $\begin{array}{l}135 \\
5\end{array}$ & $\begin{array}{l}1133 \\
4\end{array}$ & 2794 & $\begin{array}{l}141 \\
28\end{array}$ & 12.63 & 3.96 & $\begin{array}{l}16.5 \\
9\end{array}$ & 9.18 & 2.26 & $\begin{array}{l}11.4 \\
4\end{array}$ \\
\hline
\end{tabular}




\begin{tabular}{l|lll|lll|lll|lll}
\hline $\mathbf{2 0 1 8}$ & 2239 & 467 & 270 & 8229 & 4477 & 127 & 27.24 & 5.69 & 32.9 & 6.6 & 3.59 & 10.1 \\
& & & 6 & & & 06 & & & 3 & & 9 \\
\hline $\mathbf{2 0 1 9}$ & 9195 & 1707 & 109 & 2788 & 1362 & 415 & 111.1 & 20.63 & 131. & 22.14 & 10.82 & 32.9 \\
& & & 02 & 4 & 1 & 05 & 2 & & 75 & & 6 \\
\hline
\end{tabular}

The number of cases and incidence of dengue fever and severe dengue in

Mexico and Veracruz State were collected from the official website of the Mexican SINAVE (Dirección General de Epidemiología) [2] during the period from 1990 to 2019. The incidence was calculated as the number of annual new cases per 100,000 individuals. 
Highlights (Maximum 85 characters, including spaces, per bullet point).

-Novel DENV-2 and DENV- 4 genotypes have emerged in Veracruz State, Mexico.

-DENV-2 genotype Asian II and DENV-4 genotype I were both identified.

-A genotype replacement event was observed with DENV-2 and DENV-4 in Mexico.

-The concurrent introduction of new genotypes may increase the overall incidence of severe dengue. 


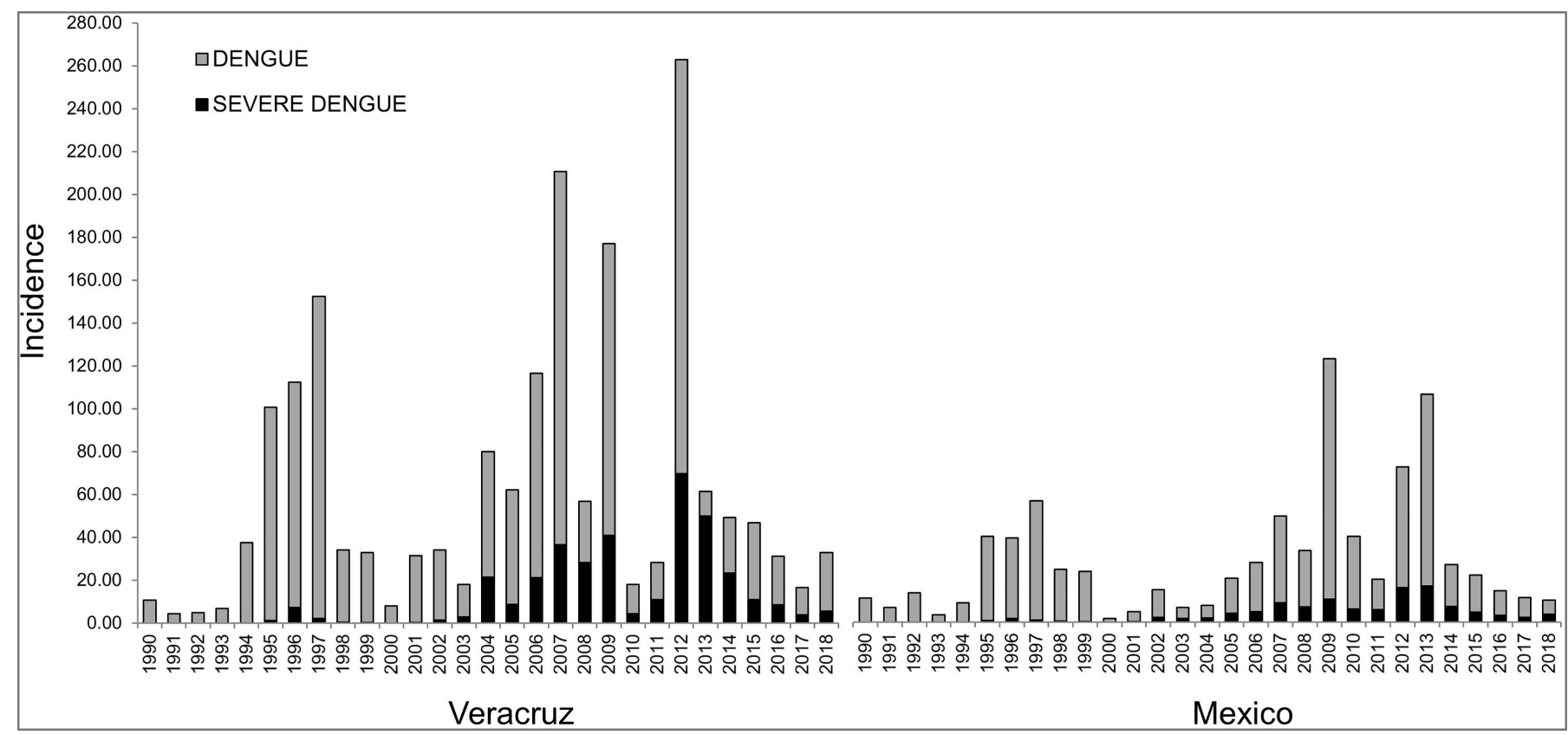

Figure 1 


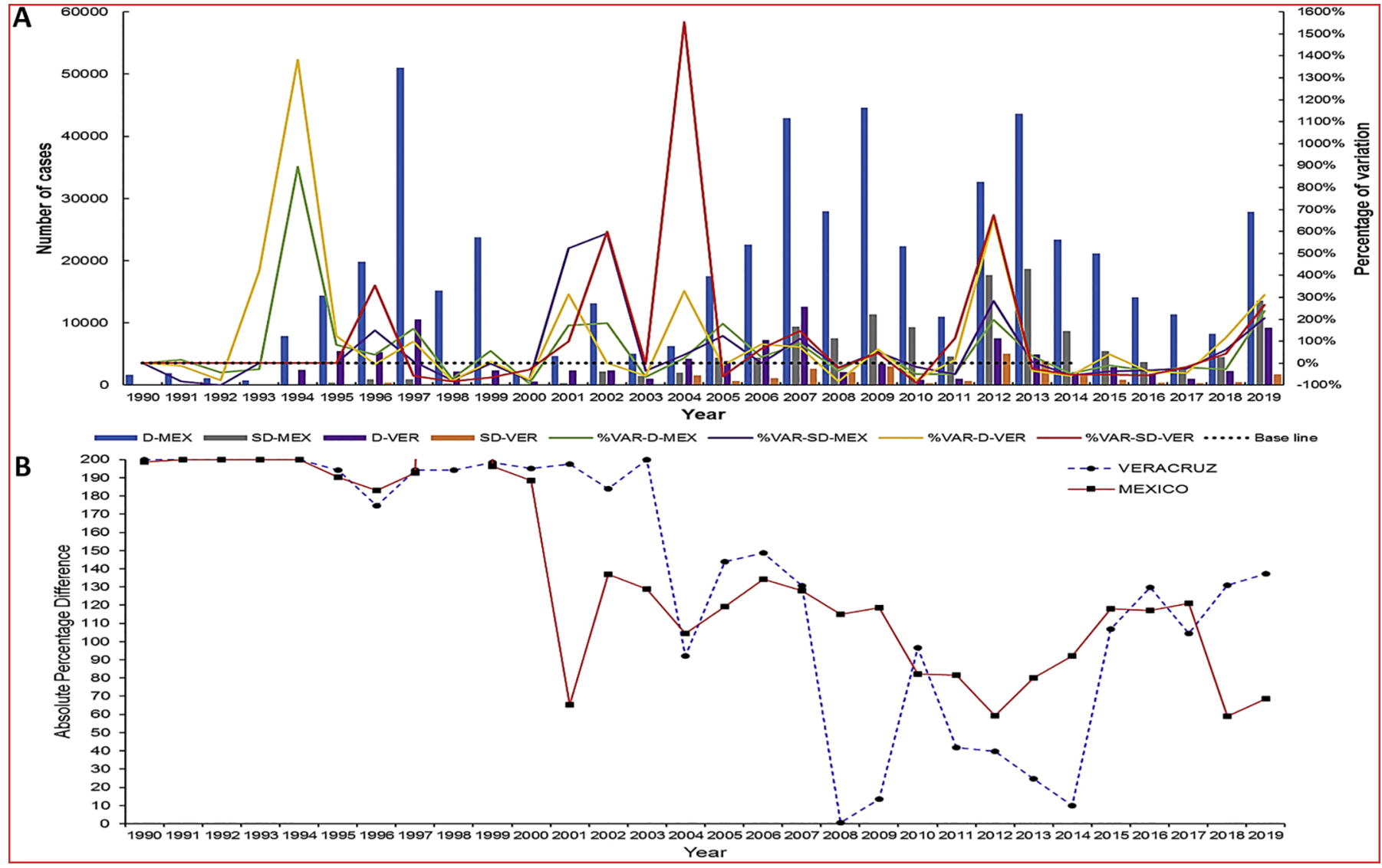

Figure 2 


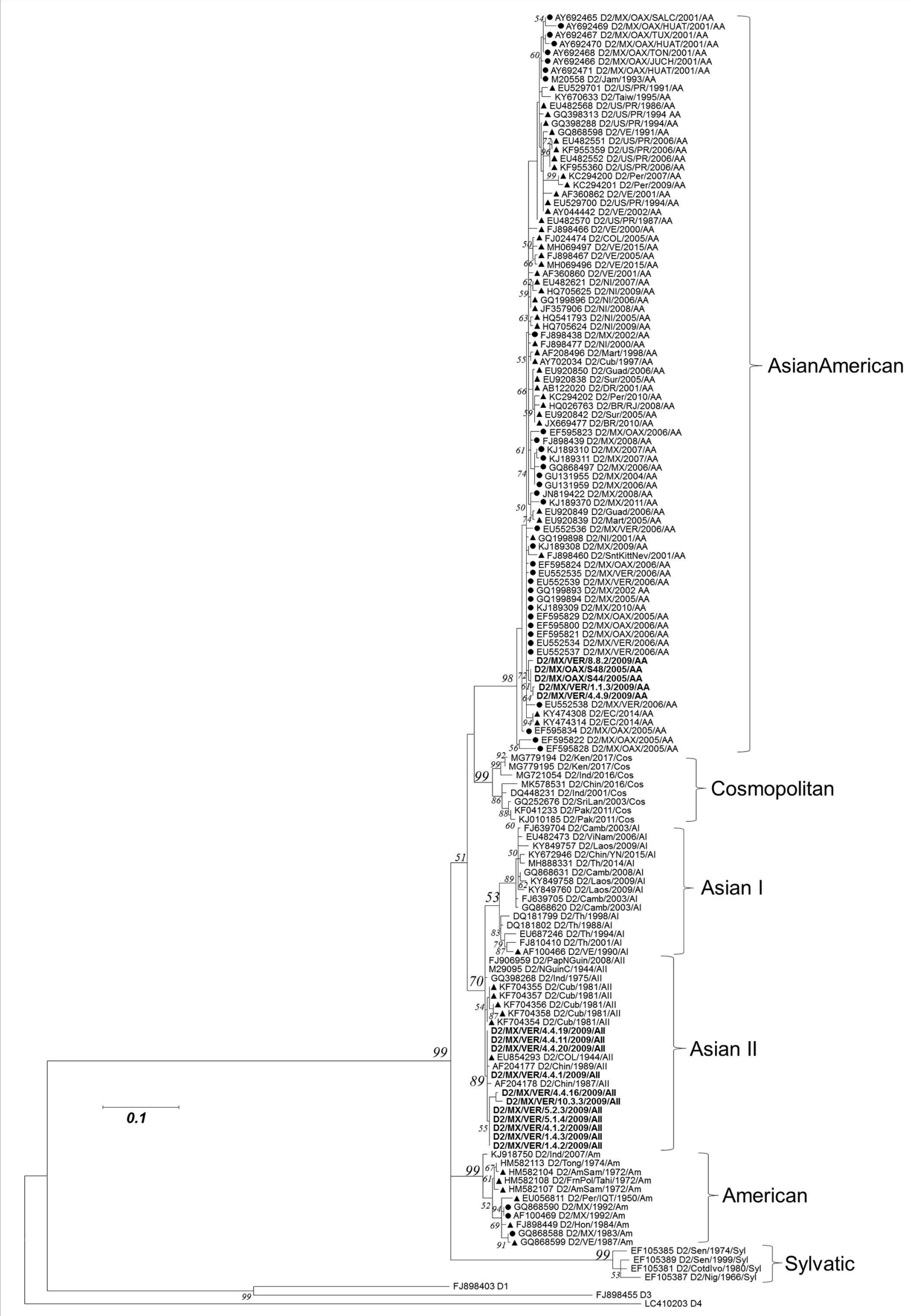


A FJ882600 D4/US/PR/1999/II

$\triangle$ EU854295 D4/US/PR/1986/I

AJ850058 D4/US/PR/1996/II

$\Delta$ GQ199881 D4/US/PR/1996//

A GQ199878 D4/US/PR/1994/I

AH011963 D4/US/PR/1994/II

I FJ024424 D4/US/PR/1998/II

64 A FJ882599 D4/US/PR/1999/I

A AH011956 D4/US/PR/1998/I

\ EU854297 D4/US/PR/1998/I

A FJ639773 D4/NE/2001/II

$\Delta$ HQ332174 D4/NE/2007/I

56 FJ639748 D4/NE/2000/

A FJ639739 D4/NE/1998/I

A FJ639745 D4/VE/1999/I

I JQ513344 D4/BR/2011/l

81 A FJ182017 D4/NE/2007/II

A HQ332172 D4/VE/2007/I

$\triangle \mathrm{FJ} 882581 \mathrm{D} 4 / \mathrm{NE} / 2007 / \mathrm{I}$

64 A EU854300 D4/NE/2007/II

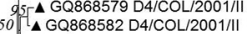

AH011965 D4/NE/1995/II

工 JN559741 D4/BR/2010//

$\triangle$ JNOB3813 D4/BR/2010/I

63 F

A F

AOS32175 D4NEI

66 .

$\triangle$ E

A FJ850095 D4/NE/2000/II

A EU854299 D 4/NE/2007/II

99

GQ868585 D4/COL/2005//I

A GQ199876 D4/VE/2007/I

FJ182016 D4/NE/2007/II

2 A GQ868583 D4/COL/2004/I

C HQ332176 D4/VE/2007/II

$\triangle$ FJ850057 D4/US/PR/1995/II

A FJ810417 D4/US/PR/1995/II

| $\triangle$ GQ199879 D4/US/PR/1994/II

$\triangle$ GQ252675 D4/US/PR/1995/II

$\triangle A H 012026$ D4/US/PR/1982/I

A JQ513341 D4/BR/2010//

A JN559740 D4/BR/1982/II

- AH012005 D4/US/PR/1987/II

A GU289913 D4/COL/1982/II

AF326573 D4/Dom/1981/II
AH011991 D4/US/PR/1992/II

A AH011991 D4/US/PR/1992/I

[AH011968 D4/CR/1996/II

$\triangle A H 012015$ D4/EC/1994/I

JF262781 D4/VE/1995/II

A FJ024476 D4/COL/1997/II

I AH02782 D4/Mait/994/I

- AH012018 DAIMX/1095/I

FJ196849 D4/Chin/1978/IA

98. LC410203 D4/Th/2017/

LC410202 D4/Th/2017/

MK614088 D4/Chin/2019//

KX224312 D4/Sin/2014/l

LC410200 D4/Th/2016/l

99 H LC410199 D4/Th/2016/

KY672957 D4/Chin/2015/I

C410198 D4/Th/2016/

LC410201 D4/Th/2016/

90 LC410197 D4/Th/2016/l

I0| LC410196 D4/Th/2016/l

96 KY672958 D4/Chin/2015// AY550909 D4/SrLank/1978/ KF955510 D4/Camb/2002/

AY618990 D4/Th/1991//

$\Delta$ JQ513345 D4/BR/2011/

$85[$ AY618992 D4/Th/2001/I

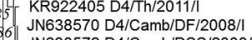

JN638572 D4/Camb/DSS/2008/

MK614093 D4/Chin/2018/l

100 MK614093 D4/Chin/2018/1

MK614090 D4/Chin/2018/l

4 MK614091 D4/Chin/2018//

AY618991 D4/Th/1977/

JQ922559 D4/Indi/1979//

$85\left[\begin{array}{l}\mathrm{J} Q 922560 \mathrm{D} 4 / \mathrm{Indi} / 2009 / 1 \\ \mathrm{~K} F 041260 \mathrm{D} 4 / \mathrm{Pak} / 2009 / 1\end{array}\right.$

10 AF289029 D4/Chin/2000/

GQ868594 D4/Phi/1956/l

AY947539 D4/Phi/1956/I

D4/MX/VER/7.1.2/2009/1

D4/MX/VER/7.1.3/2009/

100 AY618989 D4/Th/1997/II

AY618988 D4/Th/1997/

EF457906 D4/Mal/1975/Syl

JF262780 D4/Mal/1973/Sy

9 IF262779 D4/Mal/1975/Sy|

\section{Genotype II}

-Genotype 


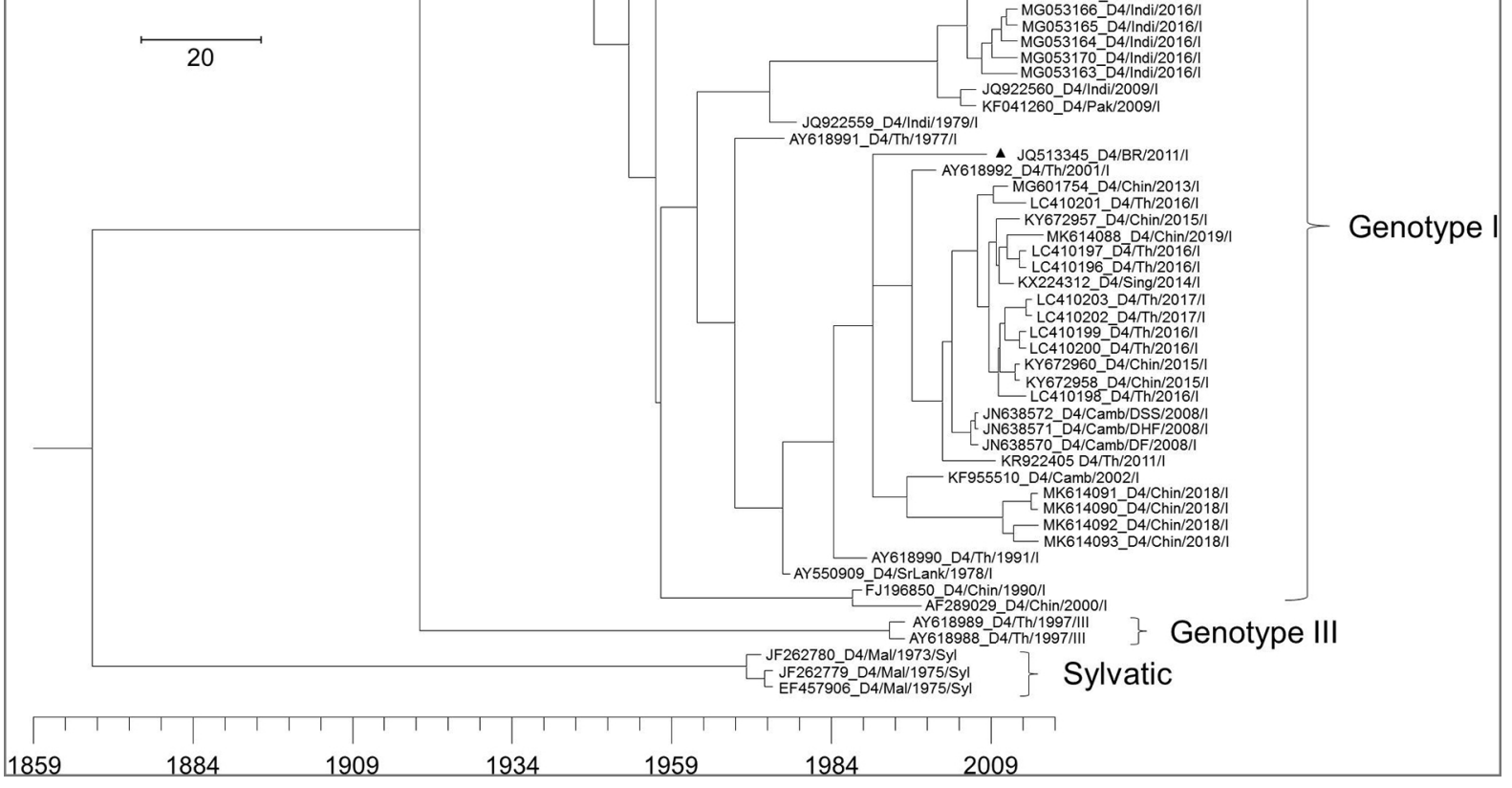

Figure 5 